УДК 669.017:620.178.16

DOI: https://doi.org/10.36910/6775-2313-5352-2019-14-2

Андрущенко М.І., к.т.н., Куликовський Р.А., к.т.н., Акритова Т.О., асп., Капустян О.С., К.Т.Н., Бриков М.М., д.т.Н., Осіпов М.Ю., К.т.н.

Запорізький національний технічний університет (ЗНТУ)

\title{
ДОСЛІДЖЕННЯ МЕТОДІВ ТА ПРИЛАДІВ ТЕРМОМЕТРІЇ ДЛЯ ВИЗНАЧЕННЯ ТЕМПЕРАТУРИ ПОВЕРХОНЬ ТЕРТЯ ДЕТАЛЕЙ ПІД ЧАС ЗНОШУВАННЯ
}

Показано, що одним із основних параметрів, який негативно впливає на зносостійкість i здатність до самозміцнення поверхні тертя деталей в процесі зномування, є температура. Особливо ие стосується матеріалів з великою кількістю в структурі метастабільного аустеніту. В залежності від хімічного складу метастабільного аустеніту негативний вплив нагрівання поверхні тертя може позначатися вже при температурах близько $100^{\circ} \mathrm{C}$. Тому для обтрунтованого вибору матеріалів для виготовлення або відновлення деталей та їх структури потрібна інформація про рівень температури, яка виникає на поверхні тертя в прочесі зношування.

В роботі розглянуті два основні способи термометрії, які найкраще підходять для визначення температури робочих поверхонь деталей. Це контактний, за допомогою термоелектричних термометрів (термопар), та безконтактний, в якому датчиком виступає напівпровідниковий імерсійний болометр БП1-2, щуо прачює в інфрачервоній частині спектру.

Запропоновано способи, схеми та пристосування для визначення температур робочих поверхонь скребків змішувачів вогнетривкої маси та штампів для пресування вогнетривів в виробничих умовах. А також поверхонь тертя зразків при випробуваннях на стандартній установиі Х4-Б та на лабораторному стенді, розробленому в ЗНТУ.

Ключові слова: зношування, температура, термометрія, термопара, лабораторні випробування, установка для випробувань, методика випробувань

Вступ. Відомо, що в багатьох випадках зношування деталей, в тому числі абразивне, відбувається при підвищених температурах $[1,2]$, які виникають, або в результаті фрикційного нагрівання, або внаслідок переробки нагрітих матеріалів. При цьому ступінь негативного впливу температури на процеси, які протікають в матеріалі під час зношування та на зносостійкість в значній мірі залежить від його структурного стану.

Ще з 60-70 років минулого століття з робіт ЗНТУ та інших наукових організацій відомо, що в умовах абразивного зношування, при температурах близьких до кімнатної, найбільша зносостійкість, як гомогенних, так і гетерогенних сплавів, досягається при наявності в металевій матриці великої кількості метастабільного аустеніту, здатного перетворюватися в мартенсит деформації в процесі зношування. Однак пізніше було встановлено, що в деяких випадках, наприклад, в умовах роботи скребків змішувачів, навіть при наявності в структурі достатньо великої кількості нестабільного аустеніту ефект підвищення зносостійкості не спостерігається. Передбачалося, що однією 3 причин цього можуть бути підвищені температури поверхні тертя. Але на той час достовірних відомостей відносно цього не було. Тому вивчення закономірностей впливу температури на повноту фазових перетворень, рівень самозміцнення поверхні тертя в процесі зношування та на зносостійкість було і $є$ актуальним до цього часу. При вирішенні цієї проблеми можна виділити дві основні складові.

По-перше, необхідно знати істинну температуру поверхні тертя деталі. Для цього потрібно вивчати, аналізувати, обирати та розробляти методи оцінки температури поверхні тертя.

По-друге, потрібно фізично моделювати умови зношування при підвищених температурах як в лабораторних так і у виробничих умовах. Це буде задачею наступної роботи за даною тематикою.

Мета даної роботи. Дослідження методів визначення температури поверхні тертя, шляхом використання контактних та безконтактних способів; аналіз і розробка пристосувань для реалізації цих методів.

Викладення основного матеріалу. На першому етапі вирішення задач дослідження проблеми зношування при підвищених температурах в ЗНТУ обиралися або розроблялися способи визначення температури поверхні тертя.

(C) Андрущенко М.І., к.т.н., Куликовський Р.А., к.т.н., Акритова Т.О., асп., Капустян О.Є., к.Т.Н., Бриков М.М., д.т.н., Осіпов М.Ю., к.т.н. 
У промисловій та науковій термометрії використовуються 2 основних методи вимірювання температури [3, 4]:

1) контактний, який реалізується первинним вимірювальним перетворювачем, що знаходиться в безпосередньому контакті з вимірювальним середовищем, яке досліджується;

2) безконтактний, який реалізується в пірометрах, а температура визначається за тепловим електромагнітним випромінюванням нагрітих тіл.

Термометри класифікують наступним чином.

Контактні:

а) термоелектричні термометри (термопари), які використовуються в діапазоні температур (від $-200^{\circ} \mathrm{C}$ до $+2200^{\circ} \mathrm{C}$ ). Їх принцип дії грунтується на зміні термоелектрорушійної сили (ТЕРС) в ланцюгу при нагріванні спаю двох різнорідних металів;

б) термометри опору, в яких використовується залежність електричного опору провідників та напівпровідників від температури. Вони поділяються на:

- металеві (від $-260^{\circ} \mathrm{C}$ до $+1100^{\circ} \mathrm{C}$ );

- напівпровідникові (від $-275^{\circ} \mathrm{C}$ до $+600^{\circ} \mathrm{C}$ );

В термометрії використовується ряд інших типів контактних термометрів: розширення, манометричні та т. п. [4]. Але аналіз принципів їх роботи та конструктивних особливостей показав, що для вирішення задач поставлених в даній роботі вони практично непридатні.

Безконтактні термометри (пірометри) поділяються на:

а) квазімонохроматичні, принцип дії яких грунтується на залежності спектральної енергетичної яскравості від температури $\left(700^{\circ} \mathrm{C} . .10000^{\circ} \mathrm{C}\right)$;

б) спектрального відношення. Методика вимірювання ними базується на використанні залежності відношення енергетичної яскравості в двох спектральних зонах від температури нагрітого об'єкта $\left(300^{\circ} \mathrm{C} . . .2800^{\circ} \mathrm{C}\right)$;

в) повного випромінювання. Їх дія заснована на використанні залежності температури від інтегральної енергетичної яскравості. На відміну від квазімонохроматичних, пірометри повного випромінювання вимірюють яскравість не у вузькій смужці випромінювання, а майже по всьому спектру $\left(50^{\circ} \mathrm{C} . . .3500^{\circ} \mathrm{C}\right)$.

Вибір того чи іншого методу та приладів для вимірювання температури залежить від багатьох факторів, основними з яких є:

- прогнозовані межі температури досліджуваного об'єкту;

- необхідна точність вимірювання температури;

- склад і властивості середовища, яке досліджується.

Аналіз конструкцій, схем роботи багатьох деталей, які працюють, в основному, в умовах абразивного зношування показав, що для визначення температури їх робочих поверхонь найкраще підходять контактний спосіб за допомогою термоелектричних термометрів (термопар) та безконтактний, в якому датчиком служить напівпровідниковий імерсійний болометр, наприклад, БП1-2, який працює в інфрачервоній частині спектру.

На цей час, із багатьох способів та приладів термометрії, найбільше поширення набули термоелектричні термометри (термопари). Це пов'язано з їх широким температурним діапазоном (від $-270^{\circ} \mathrm{C}$ до $\left.+2500^{\circ} \mathrm{C}\right)$ та, зазвичай, високою точністю $(\Delta \mathrm{T}=0,01 \mathrm{~K})$, низькою ціною, взаємозамінністю і високою надійністю. Крім того, для них характерна відносно мала інерційність.

Часто потрібно знати температуру не тільки на поверхні деталі, а й характер ії зміни за глибиною. В даному випадку метод виміру температури за допомогою термопари $є$ найбільш технологічним, а в деяких випадках і єдино можливим. Тому розглянемо цей спосіб більш детально.

Найбільш проста схема термоелектричного термометру (рис. 1) включає два різнорідні провідники (термоелектроди), які з'єднані на одному кінці, утворюючи робочий (гарячий) спай. Другі кінці термопари утворюють холодний спай. Електричний струм створюється, коли температура на одному кінці (спаї), відрізняється від температури на іншому кінці. Це явище носить назву ефекту Зеєбека, який є основою для вимірювання температури за допомогою термопар. Холодні кінці з'єднані із приладом для вимірювання напруги за допомогою проводів з металу одного типу, наприклад, міді.

На вимірювальний елемент з гарячим спаєм впливає температура технологічного процесу. Холодний або опорний спай це точка підключення поза технологічним процесом, де

(C) Андрущенко М.I., к.т.н., Куликовський Р.А., к.т.н., Акритова Т.О., асп., Капустян О.Є., к.т.н., Бриков М.М., д.т.н., Осіпов М.Ю., к.т.н. 
температура відома і де вимірюється напруга.

Відповідно до ефекту Зеєбека, напруга, яка вимірюється на холодному спаї пропорційна різниці температур гарячого і холодного спаїв. Ця напруга може називатися напругою Зеєбека, термоелектричною напругою, або термоелектричною електрорушійною силою. У міру зростання температури гарячого спаю напруга, яка спостерігається на холодному спаї, також зростає нелінійно в залежності від зростання температури. Лінійність кривої «температуранапруга» залежить від поєднання металів, які утворюють термопару [5].

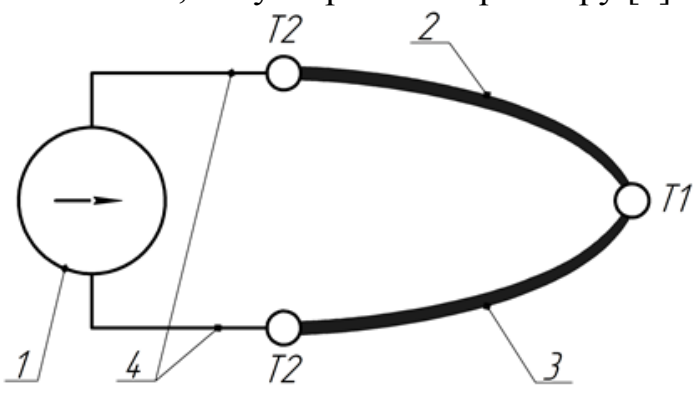

Рис. 1. Схема термоелектричного термометра

1 - вимірювальний прилад; 2, 3 - термоелектроди; 4 - з’єднувальні дроти;

T1, Т2 гарячий і холодний спай відповідно

У точках Т2 підключення провідників термопари до вимірювальної системи, наведеній на схемі (див. рис. 1), виникають додаткові ТЕРС. У результаті їхньої дії на вхід вимірювальної системи фактично надходить сума сигналів від робочої термопари та від «термопар», які виникли в точках підключення. Це призводить до виникнення похибок при вимірюванні температури. Для правильного вимірювання температури на одному (першому) із спаїв, необхідно підтримувати інший (другий) спай при відомій постійній температурі, щоб виміряна ЕРС виявлялася функцією температури робочого спаю. 3 метою підтримки в термовимірювальному контурі умов, при яких «паразитний» вплив ЕРС холодного спаю було б виключено, необхідно постійно компенсувати напругу, яка на ньому виникає. Найбільш поширеними способами компенсації є використання схем, наведених на рисунку 2 [6].

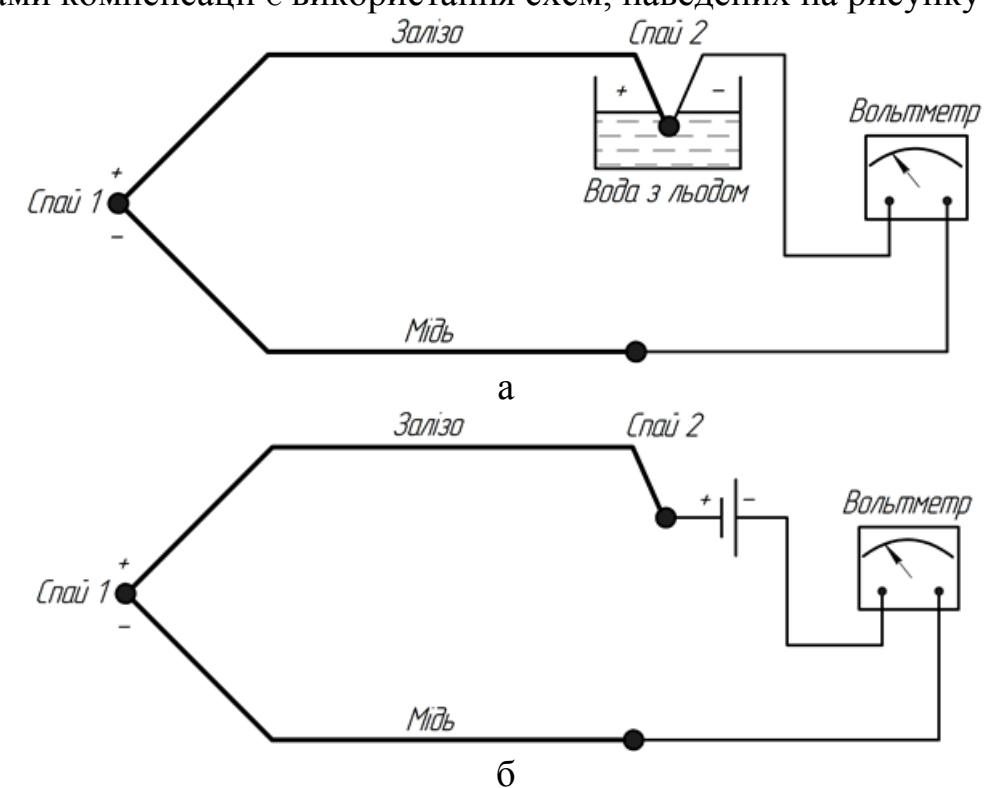

Рис. 2. Схеми підключення термопари з компенсацією дії холодного спаю шляхом його розміщення у ємності з водою і льодом (а) та з приєднаним до вимірювального контуру джерела додаткової напруги (б)

За першим способом, з метою досягнення стабільних умов роботи термоелектричного термометра необхідно помістити другий спай, тобто місця його приєднання з дротами, які з'єднують термоелектроди з вимірювальним приладом в ємність заповнену водою, в якій плаває лід (див. рис. 2 а). Таким чином на другому спаї буде триматися постійна температура

(C) Андрущенко М.І., к.т.н., Куликовський Р.А., к.т.н., Акритова Т.О., асп., Капустян О.Є., К.Т.н., Бриков М.М., д.т.н., Осіпов М.Ю., к.Т.н. 
танення льоду, що виключить утворення похибки при вимірювання ТЕРС.

Але часто термопари застосовуються в мобільних портативних приладах, в яких задіяння першого способу компенсації практично неможливо. В таких випадках послідовно приєднується до вимірювального контуру джерело додаткової напруги (див. рис. 2 б), ЕРС якого матиме протилежний напрямок і за величиною буде завжди точно дорівнювати ЕРС «холодного спаю».

Важливою складовою розробки методики вимірювання температури є технологія виготовлення термопар. Утворення робочого кінця (з'єднання дротів) може виконуватися різними способами, включаючи скручування, стиснення, пайку, в тому числі й високотемпературну, а також різні види зварювання, наприклад, зварювання вузьким швом або зварювання в стик. Щоб отримати найкращі робочі характеристики, гарячий спай повинен бути механічно міцним, електрично безперервним, не забруднений ніякими хімічними домішками матеріалів, які використовуються при зварюванні або паянні. Необхідно відзначити, що гарячий спай отриманий шляхом скручування дротів, дуже швидко втрачає свої властивості, $\mathrm{i}$ використовувати такий спосіб отримання робочого кінця не рекомендується. 3 нашого досвіду, найбільш технологічним і надійним способом отримання робочого спаю термопар $\epsilon$ зварювання кінців термоелектродів в порошкоподібному графіті, який знаходиться в металевій ємності. Напруга від трансформатора створюється між корпусом ємності та скрученими кінцями термопари, які занурюються в графіт. При плавному вийманні термопари із графіту збуджується дуга і утворюється робочий спай.

Існує дуже велика кількість типів термопар, вибір яких залежить від декількох факторів наведених вище. Досвід ЗНТУ у використанні термометрії при дослідженні процесів зношування деталей та зразків показує, що найбільш прийнятними для замірів температури поверхні тертя можна вважати термопари:

- тип Е (хромель-константан), використовується для вимірювання температур в діапазоні від $-40^{\circ} \mathrm{C}$ до $+900^{\circ} \mathrm{C}$. Має високу чутливість;

- тип К (хромель-алюмель), використовується для вимірювання температур в діапазоні від $-200^{\circ} \mathrm{C}$ до $+1000^{\circ} \mathrm{C}$ (рекомендована межа, залежить від діаметра термоелектродного дроту); - тип L (хромель-копель), використовується для вимірювання температур в діапазоні від $-200^{\circ} \mathrm{C}$ до $+800^{\circ} \mathrm{C}$ (рекомендована межа, що залежить від діаметра термоелектродного дроту).

В якості прикладу використання термопар можна розглянути методику виміру температур поверхні тертя скребків обладнання для змішування абразивних мас, яка була розроблена в ЗНТУ. Необхідно було встановити максимальну температуру, яка виникає на зношуваній поверхні скребка, а також характер розподілу температури по глибині поверхневого шару.

3 цією метою, на підприємстві по виготовленню вогнетривів, були випробувані збірні скребки (рис. 3), в робочу кромку яких виводились шість хромель-копелевих термопар; їх робочі спаї розташовувались на різній відстані від зношуваної поверхні скребка (рис. 4). Вільні кінці термопар за допомогою компенсаційних дротів через щитковий перемикач, який виключає появи різного роду перешкод і наведень в процесі роботи, були виведені на лабораторний компенсаційний прилад ЛКС4-003. Реєстрацію температури проводили в процесі промислової експлуатації змішувача при встановленому на підприємстві ритмі перемішування вогнетривкої сировини.

В результаті досліджень характеру зношування в умовах експлуатації скребків було встановлено, що їх поверхні тертя нагріваються до $500^{\circ} \mathrm{C} . .550^{\circ} \mathrm{C}$. При цьому, не дивлячись на те, що температура при віддалені від поверхні скребка різко знижується (рис. 5), перетворення метастабільного аустеніту в мартенсит деформації й самозміцнення поверхні тертя не відбуваються. Отримані результати допомогли обгрунтовано вибрати інші матеріали для наплавлення скребків, ніж ті, які використовувались до цього і розробити технологію зміцнення робочих поверхонь скребків.

(C) Андрущенко М.І., к.т.н., Куликовський Р.А., к.т.н., Акритова Т.О., асп., Капустян О.Є., К.Т.н., Бриков М.М., д.т.н., Осіпов М.Ю., к.т.н. 


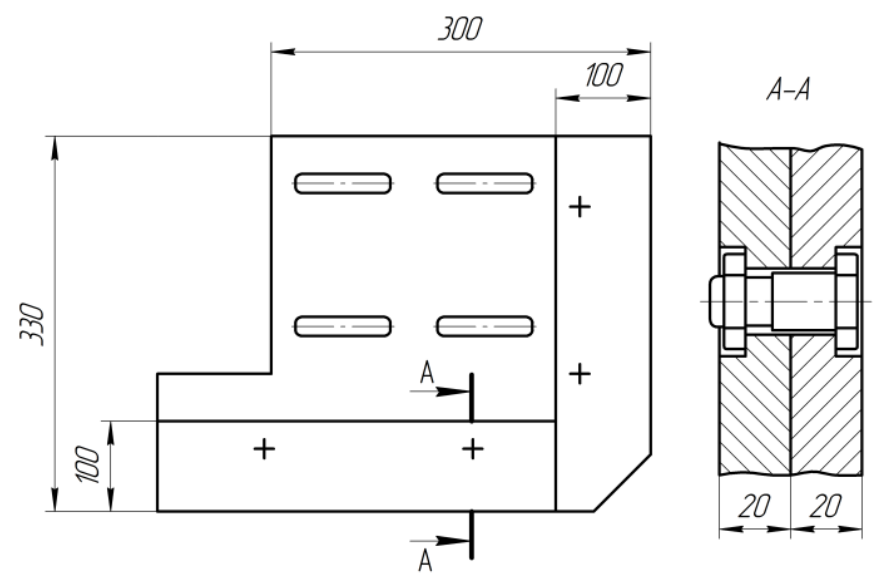

Рис. 3. Схема збірного скребка установки для змішування вогнетривких мас

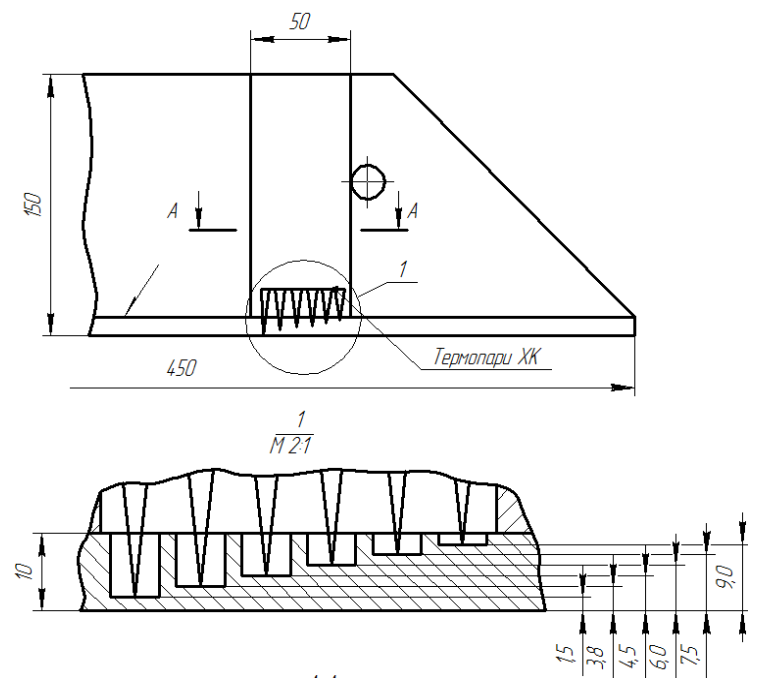

Рис. 4. Схема установки термопар в скребку для замірів температур в процесі зношування

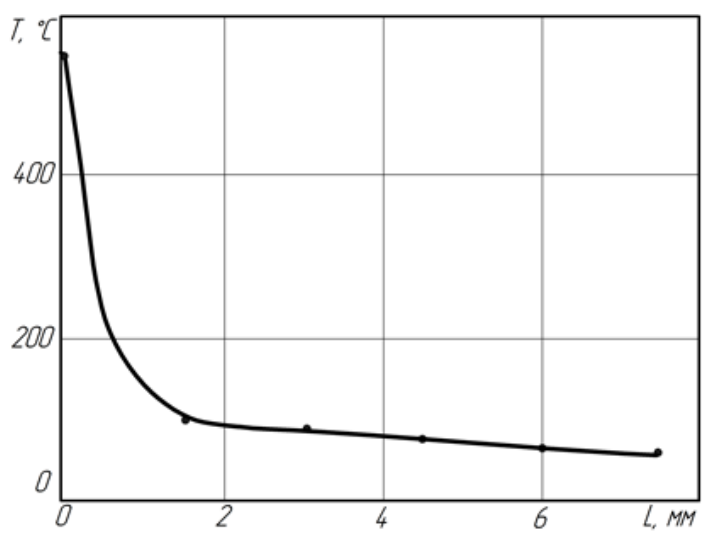

Рис. 5. Характер зміни температури на робочій кромці скребка по мірі віддалення від поверхні тертя

Для визначення температури поверхні штампів для пресування вогнетривких виробів розроблено нескладне пристосування, яке дозволяє за короткий час, практично не перериваючи роботи преса зробити виміри. Пристосування (рис. 6) включає хромель-копелеву термопару, розклепаний робочий спай, якої розміщений в поглиблення пластинки 3 поліуретану матеріалу, що має достатню стійкість до нагрівання, пружність і низьку теплопровідність. При цьому, поглиблення в пластинці виконувалось такої глибини, щоб розклепаний спай надійно міг контактувати 3 поверхнею штампа. Пластинка 3 термопарою прикріплена до пружини стиснення, яка, в свою чергу, закріплена на сталевому диску. На цьому ж диску закріплено постійний магніт, таким чином, що спай термопари знаходиться на осі магніту. Загальний розмір незжатої пружини і товщина пластинки на 3 мм - 5 мм більше висоти магніту. Кінці термопари через отвори в пластинці виведені до приладу. Для виміру температури штампа пристосування встановлювалося на його поверхні. При цьому за рахунок дії магніту пружина стискалась, створюючи зусилля на поліуретанову пластинку, яка пружно деформуючись, обтискала спай термопари. Тим самим практично виключався тепловідвід від спаю термопари. Через 5 c - 10 с за показниками приладу визначалась температура поверхні штампа.

(C) Андрущенко М.І., к.т.н., Куликовський Р.А., к.т.н., Акритова Т.О., асп., Капустян О.Є., К.Т.н., Бриков М.М., д.т.н., Осіпов М.Ю., к.Т.н. 


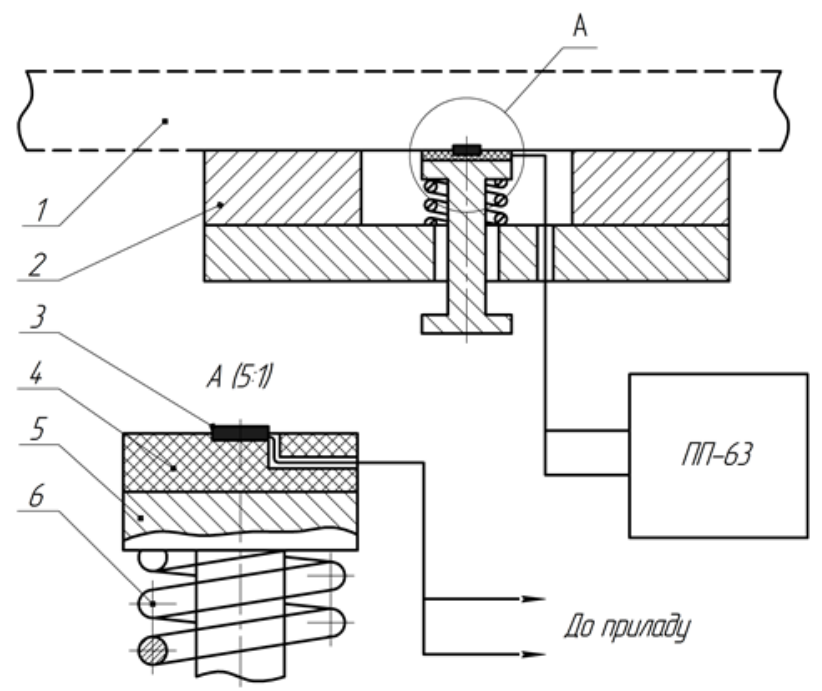

Рис. 6. Пристосування для виміру температури на поверхні штампа в процесі роботи 1 - штамп; 2 - магніт; 3 - спай термопари; 4 - поліуретанова пластина; 5 - шток; 6 пружина

Визначення температури поверхні тертя зразків при випробуваннях на зношування закріпленим абразивом на установці Х4-Б проводили з використанням зразка-датчика (рис. 7) [7]. Матеріалом зразка 1 служить хромель, до якого приварюється тонкий копелевий дріт 2. Таким чином, виходить гарячий спай хромель-копелевої термопари (холодний спай 6 знаходиться у водно-льодовій суміші), який при зношуванні зразка поступово виходить на поверхню тертя. ТЕРС ланцюга термопари реєструється вимірювачем 4 i автоматично записується. В деякий момент гарячий спай зношується настільки, що настає його руйнування. За значенням ТЕРС, виміряної в момент, який передує розриву гарячого спаю, визначається температура поверхні тертя датчика. Передбачається, що при випробуваннях зразків, теплопровідність яких близька до теплопровідності хромелю (залізовуглецеві сплави), температура їх поверхні тертя буде приблизно дорівнювати температурі поверхні тертя датчика в тих же умовах випробувань.

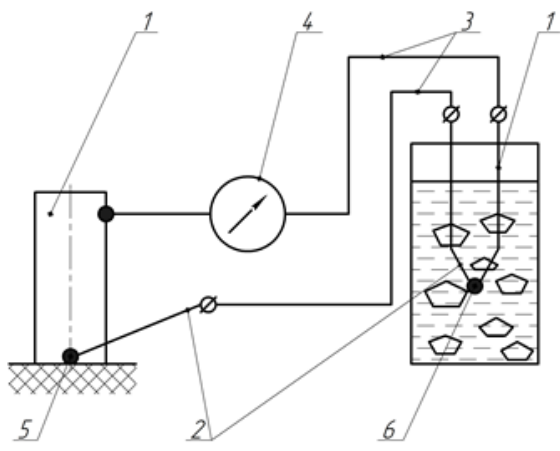

Рис. 7. Схема вимірювання температури поверхні тертя зразка із хромелю при абразивному зношуванні

1 - зразок із хромелю; 2 - копелевий дріт; 3 - компенсаційні дроти; 4 - вимірювач TEPC;

5 - гарячий спай; 6 - холодний спай

Зазначеним способом були проведені вимірювання температури поверхні тертя датчика при випробуваннях на абразивне зношування при різних швидкостях ковзання по абразиву. При мінімальній частоті обертання барабану $12,5 \mathrm{xв}^{-1}$ швидкість ковзання становить $70 \mathrm{~mm} / \mathrm{c}$. Максимальна частота обертання, при якій були проведені випробування, становила $630 \mathrm{xв}^{-1}$, що відповідає швидкості ковзання 3533 мм/с. Після обробки записів результатів вимірювань ТЕРС для кожної швидкості ковзання по абразиву отримані залежності виду «швидкість ковзання температура» (рис. 8) [7]. Останні значення температури перед руйнуванням спаїв термопари для кожної $з$ швидкостей ковзання відповідають дійсній температурі поверхні тертя. Всі

(C) Андрущенко М.І., к.т.н., Куликовський Р.А., к.т.н., Акритова Т.О., асп., Капустян О.Є., К.Т.н., Бриков М.М., д.т.н., Осіпов М.Ю., к.Т.н. 
випробування 3 визначення температури поверхні тертя датчика проводили на абразивній шкірці при одноразовому проходженні зразка по одній і тієї ж поверхні абразиву.

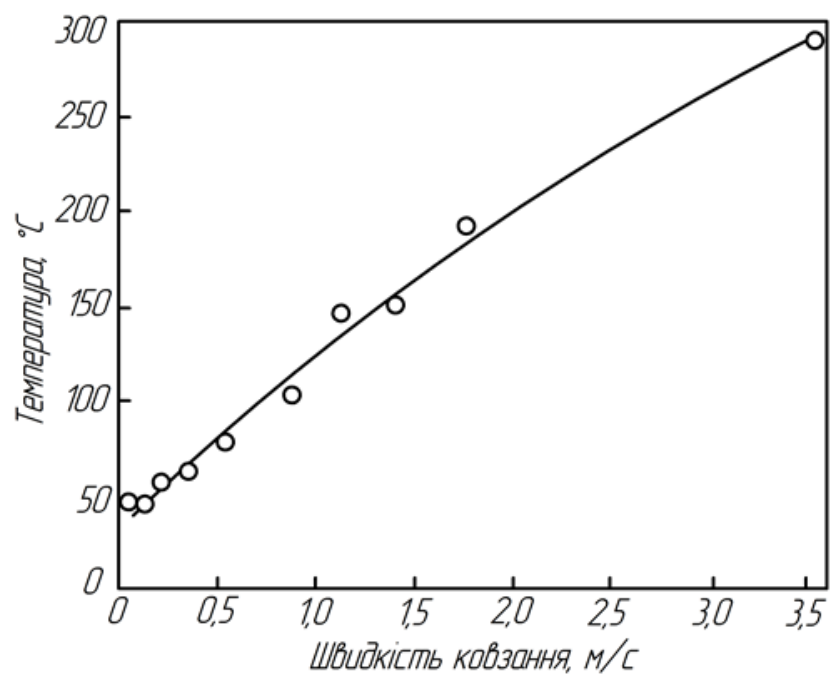

Рис. 8. Температура поверхні тертя зразків при різній швидкості ковзання по абразиву

Як і слід було очікувати, залежність має лінійний характер. Лише при температурі $290^{\circ}$ С спостерігається невелике відхилення від прямої в бік меншої температури. Ймовірно, в цих умовах вже починає проявлятися вплив тепловідведення з поверхні тертя вглиб зразка.

Необхідно відзначити, що навіть при мінімальній швидкості ковзання зразка по абразиву (70 мм/с), фіксується деякий фрикційний нагрів поверхні тертя. Це ще раз вказує на те, що в реальних умовах роботи деталей машин навряд чи зустрічається абразивне зношування абсолютно безфрикційного нагрівання.

Крім дослідження абразивного зношування вчені, часто вимірювали температуру і при інших видах поверхневого руйнування. Зокрема, в збірнику наукових праць [8] представлена схема вимірювання температури при сухому ковзанні метал по металу (рис. 9). В даному випадку, по полірованому сталевому кільцю ковзає константановий дріт. Ці метали утворюють термопару і в процесі ковзання ТЕРС фіксується осцилографом. При зрізанні «містків зчеплення», які виникають при терті, розвиваються температури близько $1000^{\circ} \mathrm{C}$, які тривають менше $10^{-4}$ с. Навіть при наявності мастильних плівок також можуть бути отримані високі поверхневі температури [8]. Вже при досить малих нормальних зусиллях і швидкостях ковзання температури можуть складати сотні градусів. Інформація про їх рівень може мати велике значення для теорії та практики граничного тертя, а також для вибору і розробки мастильних матеріалів.

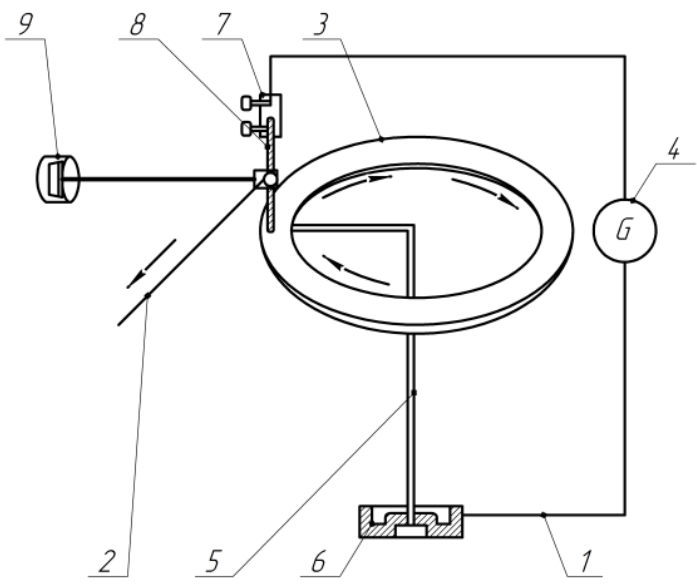

Рис. 9. Спрощена схема пристосування для вимірювання ТЕРС, яка виникає між поверхнями зразка і стального кільця при ковзанні

1 - мідний дріт; 2 - натяжний дріт для вимірювання сили тертя; 3 - стальне поліроване кільце; 4 - вимірювальний прилад; 5 - стойка; 6 - основа; 7 - державка; 8 - зразок; 9 - рухомий вантаж

(C) Андрущенко М.I., к.т.н., Куликовський Р.А., к.т.н., Акритова Т.О., асп., Капустян О.Є., К.Т.н., Бриков М.М., д.т.н., Осіпов М.Ю., к.т.н. 
Характерною особливістю абразивного зношування металевих матеріалів є дуже мала площа реального контакту абразивних зерен із зношуваною поверхнею, в порівнянні із загальною площею поверхні тертя. Тому, навіть при невеликому загальному навантаженні, напруження в місцях контакту досягають значень, достатніх для пластичної деформації металу, який зношується і локального підвищення температури.

Існують три рівня підвищеної температури в зоні поверхні тертя металевих матеріалів при абразивному зношуванні:

1) температура спалаху в зоні одиничного контакту абразивного зерна $з$ поверхнею тертя. Вона $\epsilon$ максимальною контактною температурою і може досягати значень декількох сотен градусів Цельсія на дільницях, розміром від частки мікрона до декількох мікрон в перетині. Загальна тривалість спалаху складає від декількох наносекунд до декількох мікросекунд [9];

2) середня температура поверхні тертя, що виникає в результаті сумарної дії температурних спалахів в контактах. Вона приблизно вдвічі нижча за температуру спалаху [9, $10]$;

3) температура в обсязі тіла, яка інтенсивно знижується зі збільшенням відстані від поверхні (див. рис. 5).

Вимірювання об'ємної температури металевих деталей і зразків при абразивному зношуванні не дозволяє судити про ii рівень на поверхні тертя через великий градієнт перпендикулярний до поверхні, яка зношується. Результати вимірювання середньої температури поверхні тертя дозволяли б опосередковано визначати температуру на кожному 3 трьох рівнів фрикційної взаємодії абразиву і матеріалу.

Розглянуті раніше методи дозволяють реєструвати деяку усереднену величину поверхневої температури при терті абразивних частинок. У той же час процеси зношування відбуваються при впровадженні та відносному переміщенні окремих зерен, тому представляє інтерес визначити температуру в одиничному контакті.

В ЗНТУ Пугачовим Г. О. [11] розроблено прилад для вимірювання температури в одиничному контакті (рис. 10).

Виміряти температуру в одиничному контакті дає можливість застосування методу природної термопари [12], яка є практично безінерційною, так як роль робочого спаю в даному випадку виконує сам контакт елементів, що ковзають один відносно одного. Розроблене пристосування на базі приладу ПМТ-3 дозволяє визначити контактні температури при терті в залежності від навантаження і швидкості ковзання.

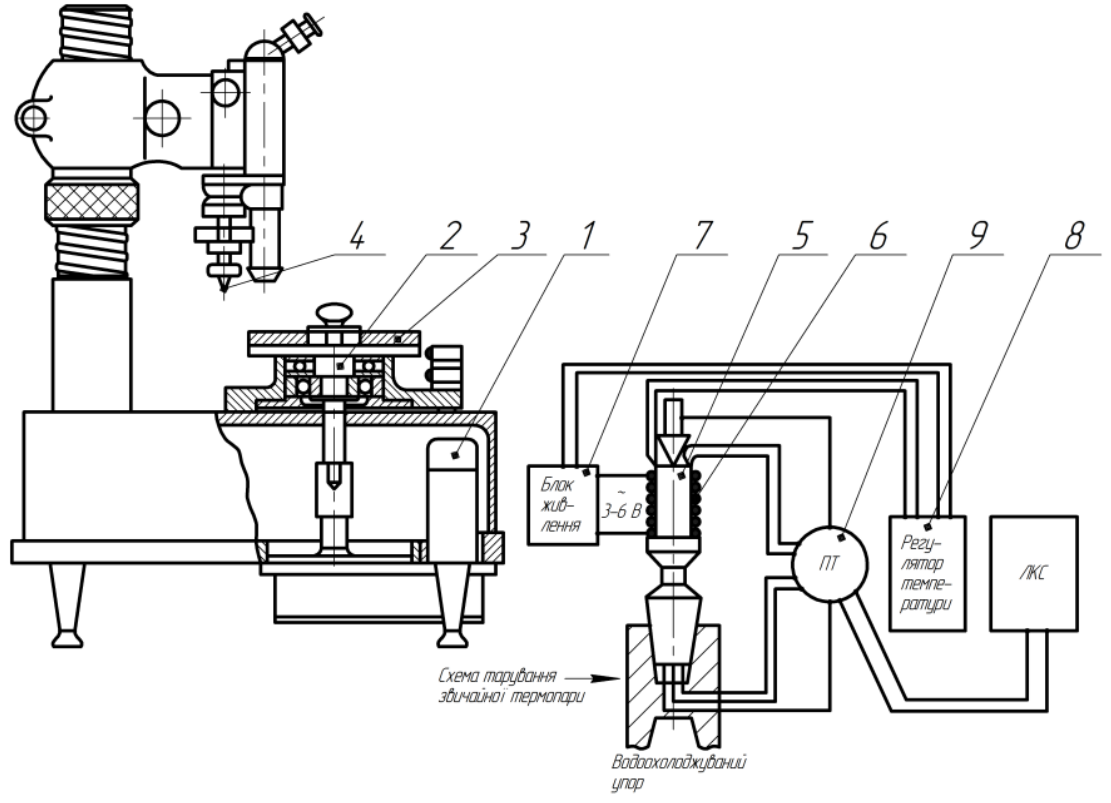

Рис. 10. Схема пристосування для визначення контактної температури при терті

На корпусі мікротвердоміра розташований вузол приводу зразка, що складається 3 мотор-редуктора 1 і планшайби 2, яка обертається. Зразок 3 діаметром 110 мм і товщиною 10 мм 3 полірованою робочою поверхнею закріплюється на планшайбі. Як матеріал зразка була

(C) Андрущенко М.I., к.т.н., Куликовський Р.А., к.т.н., Акритова Т.О., асп., Капустян О.Є., К.Т.н., Бриков М.М., д.т.н., Осіпов М.Ю., к.т.н. 
прийнята сталь 140Х12Ф1. Індентор 4, виконаний 3 твердого сплаву ВК-15, у вигляді чотиригранної піраміди 3 кутом при вершині $130^{\circ}$ встановлюється замість алмазного. Електрична схема живлення електродвигуна дозволяє автоматично відключати його після кожного обороту планшайби. Практично миттєва зупинка зразка забезпечується електрогальмами на двигуні. Час одного обороту визначається електричним секундоміром.

Навантаження індентора до 200 г здійснювалось за допомогою вантажів приладу ПМТ3. Більш високі навантаження створювалися спеціальною приставкою. ТЕРС, яка виникає в контакті зразок - індентор при ковзанні, реєструвалась на стрічці самописця ЛКС.

Тарування природних термопар проводилось за спеціально розробленою методикою. Тарувальний пристрій (див. рис. 10) складається зі зразка 5, нагрівача 6, блоку живлення 73 контрольно-регулюючим пристроєм 8 , які працюють в комплекті зі штучною хромелькопелевою термопарою (ХК), двох контрольних ХК термопар, з яких одна розташована у водоохолоджуваного кінця зразка 5 , а інша - в зоні контакту індентора і перемикача 9. ТЕРС всіх чотирьох термопар по черзі записувалась на стрічці самописця. Знаючи температуру на торці зразка 5 за контрольною термопарою і ТЕРС природної термопари, проводиться іiі тарування.

В результаті досліджень на цьому приладі сталі 140Х12Ф1 були визначені закономірності зміни температури в залежності від навантаження і швидкості ковзання (рис. 11). Встановлено, що при малих швидкостях ковзання (5 мм/с) температури в контакті сталь 140Х12Ф1 - твердий сплав ВК-15 знаходяться на рівні кімнатних та практично не змінюються 3 ростом навантаження від $2 \mathrm{H}$ до $298 \mathrm{H}$. У той же час збільшення швидкості ковзання до 700 мм/с в тому ж діапазоні навантажень призводить до зростання контактних температур до $550^{\circ}$ C. Отримана інформація про температуру в одиничному контакті дозволила обгрунтовано обирати режими випробувань зразків на лабораторних стендах, а також пояснювати отримані при цьому результати. Крім того, ці данні дозволяють орієнтовно прогнозувати усереднену температуру поверхні тертя деталей виробничого обладнання (бандажі прес-вальців, ножі сит для протирання абразивних мас та ін.), виходячи з умов їх роботи.

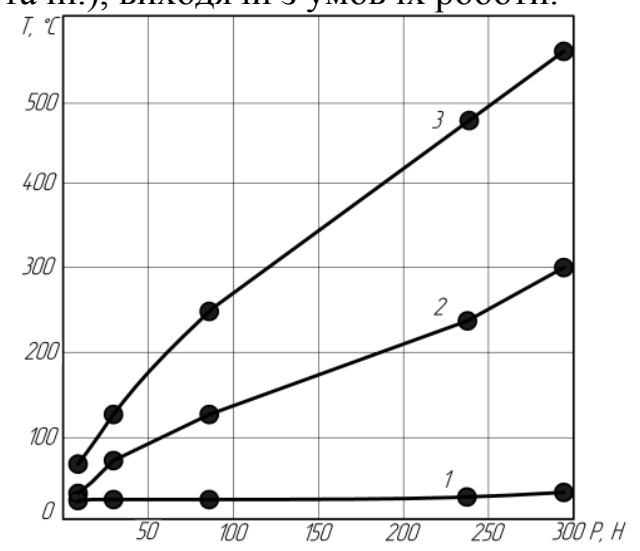

Рис. 11. Залежність температури поверхні при терті в одиничному контакті від навантаження та швидкості ковзання $1-\mathrm{V}=5 \mathrm{~mm} / \mathrm{c} ; 2-\mathrm{V}=300 \mathrm{~mm} / \mathrm{c} ; 3-\mathrm{V}=700 \mathrm{~mm} / \mathrm{c}$

В деяких випадках через конструктивні особливості деталей або схеми їх роботи, використання термопар для оцінки температури поверхні тертя буває неможливим або значно ускладненим. В такому разі можна застосовувати безконтактні способи вимірювання температури при фрикційному нагріванні. Вони засновані на реєстрації інтенсивності теплового або іншого випромінювання від нагрітого об'єкту.

Для безконтактного вимірювання температури на поверхні зразка при великих швидкостях ковзання абразивної маси, був розроблений прилад [11], датчиком якого служить напівпровідниковий імерсійний болометр БП1-2 (рис. 12).

(C) Андрущенко М.І., к.т.н., Куликовський Р.А., к.т.н., Акритова Т.О., асп., Капустян О.Є., К.Т.н., Бриков М.М., д.т.н., Осіпов М.Ю., к.т.н. 


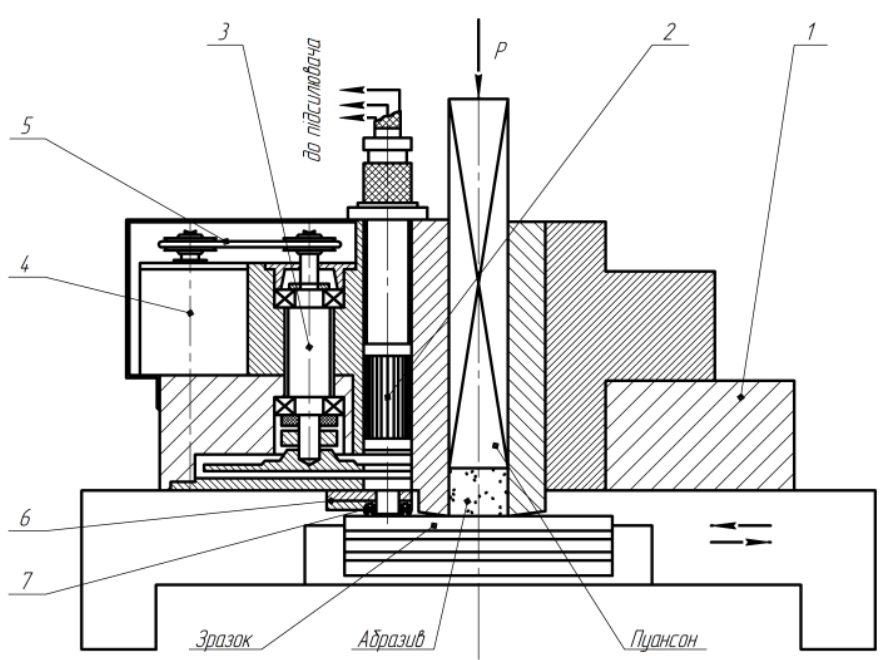

Рис. 12. Схема вузла модулятора для вимірювання температури зразка

У верхній плиті вузла тертя встановлений болометр 2, світловий потік, що падає на нього, перетинається модулятором 3. Під дією інфрачервоних променів опір болометра, розташованого в фокусі германієвої лінзи, змінюється пропорційно довжині хвилі. Германій пропускає довжину хвилі до 5-6 мкм, що відповідає максимальному випромінюванні при температурі до $600^{\circ} \mathrm{C}$ [11]. Привід модулятора складається з електродвигуна постійного струму 4 і ремінної передачі, частота модуляції регулюється числом обертів електродвигуна. Так як світловий потік залежить від температури і випромінювальної здатності тіла, то для очищення поверхні зразків, яка зношується, передбачено пристрій 6 з ущільнювальним гумовим кільцем 7 (див. рис. 12).

Таким чином, існує ряд способів, приладів, обладнання за допомогою яких можна визначати температуру поверхонь тертя та пришовної зони. Їх вибір залежить від конструкції та умов роботи деталей та зразків.

\section{Висновки}

1. Одним із основних параметрів умов роботи деталей, який негативно впливає на зносостійкість та здатність до самозміцнення поверхні тертя в процесі зношування $\epsilon$ температура.

2 Найбільш чутливими до підвищення температури поверхні тертя є матеріали 3 великою кількістю в структурі метастабільного залишкового аустеніту здатного до перетворення в процесі зношування в мартенсит деформації.

3. Частіш за все підвищення температури поверхні тертя може відбуватися або в результаті фрикційного нагрівання, або ж в наслідок переробки нагрітих матеріалів.

4. Для визначення температури робочих поверхонь деталей найкраще підходять: контактний спосіб, за допомогою термоелектричних термометрів (термопар); безконтактний, в якому датчиком служить напівпровідниковий імерсійний болометр БП1-2, що працює в інфрачервоній частині спектру.

5. Використання термоелектричних термометрів (термопар) за запропонованими схемами і пристосуваннями дозволив встановити, що температура робочих поверхонь скребків змішувачів може підвищуватись до $500^{\circ} \mathrm{C}$. А температура поверхонь штампів для пресування вогнетривів, в результаті примусового нагрівання може сягати $200^{\circ} \mathrm{C}$.

6. При випробуваннях на установці Х4-Б при збільшенні швидкості ковзання від $0,1 \mathrm{~m} / \mathrm{c}$ до 3,5 м/с температура поверхні тертя збільшується від $40^{\circ} \mathrm{C}$ до $290^{\circ} \mathrm{C}$.

\section{Інформаційні джерела}

1. Коваль А. Д. Абразивное изнашивание железоуглеродистых сплавов при фрикционном нагреве / А. Д. Коваль, М. Н. Брыков // Трение и износ. - 2010. - №3. С.305-311.

2. Осипов М.Ю., Холод А.В., Андрущенко М.И. Изменение интенсивности фазовых превращений в процессе изнашивания и износостойкости в зависимости от температуры испытаний / Тези доповідей XIII Міжнародної науково-технічної конференції "Нові конструкційні сталі та стопи і методи їх оброблення для підвищення надійності та

(C) Андрущенко М.І., к.т.н., Куликовський Р.А., к.т.н., Акритова Т.О., асп., Капустян О.Є., К.Т.н., Бриков М.М., д.т.н., Осіпов М.Ю., к.т.н. 
довговічності виробів". - Запоріжжя: ЗНТУ, 2014. - С. 129-130.

3. Теплотехнические измерения и приборы. Учебник для вузов по специальности «Автоматизация теплоэнергетических процессов». / Преображенский В. П. - 3-е изд., перераб. - М.: «Энергия», 1978. - 704 с. 1990. $208 \mathrm{c}$

4. Крамарухин Ю. Е. Приборы для измерения температуры. - М.: Машиностроение,

5. Никонов Н.В. Термопары. Типы, характеристики, конструкции, производство. М.: ООО «МТК «Метотехника», 2015. - 62 с.

6. Схемы включения и компенсации термопар [Електронний ресурс] / Школа для електриків. - Режим доступу: http://electricalschool.info/spravochnik/izmeren/1936-skhemyvkljuchenija-i-kompensacii.html - 05.06.2019 p. - Загол. з екрану.

7. Брыков М. Н. Определение температуры металлических материалов при испытаниях на абразивное изнашивание / М. Н. Брыков // Вісник технологічного університету Поділля. 2004. - № 1, Ч. 1. - С. 38-41. $452 \mathrm{c}$.

8. Испытания металлов. Сборник статей под. ред.. К. Нитцше М.: Металлургия, 1967. -

9. Bhushan B. Introduction to Tribology. - New York: John Wiley, 2002. - 700p.

10. М.Н.Брыков. Определение допустимой скорости скольжения образцов по абразиву при стандартных испытаниях на изнашивание // Нові матеріали і технології в металургії та машинобуду-ванні: Збірник наукових праць Запорізького держ. техн.ун-та. - 2000. - N1. - С.3941.

11. Пугачов, Г.А. Исследование износостойкости сплавов при трении в абразивной массе и разработка наплавочных материалов [Текст]: дис. ... канд. техн. наук / Г.А. Пугачов. Запорожье, 1979. - $216 \mathrm{c}$.

12. Чичинадзе А.В. Расчет и исследование внешнего трения при торможении. М.: Наука, 1967. - 231 с.

Андрущенко М.И., к.Т.Н., Куликовский Р.А., к.т.н., Акрытова Т.А., асп., Капустян О.Е., к.т.н., Брыков М.Н., д.т.Н., Осипов М.Ю., к.т.н.

Запорожский национальный технический университет (ЗНТУ)

\section{ИССЛЕДОВАНИЕ МЕТОДОВ И УСТРОЙСТВ ТЕРМОМЕТРИИ ДЛЯ ОПРЕДЕЛЕНИЯ ТЕМПЕРАТУРЫ ПОВЕРХНОСТЕЙ ТРЕНИЯ ДЕТАЛЕЙ В ПРОЦЕССЕ ИЗНАШИВАНИЯ}

Показано, что одним из основных параметров, который негативно влияет на износостойкость и способность к самоупрочнению поверхности трения деталей в процессе изнашивания, является температура. Особенно это касается материалов с большим количеством в структуре метастабильного аустенита. В зависимости от химического состава метастабильного аустенита негативное влияние нагрева поверхности трения может сказываться уже при температурах около $100^{\circ}$ С. Поэтому для обоснованного выбора материалов для изготовления или восстановления деталей и их структуры нужна информация об уровне температуры, возникающей на поверхности трения в процессе изнашивания.

В работе рассмотрены два основных способа термометрии, которые лучше всего подходят для определения температуры рабочих поверхностей деталей. Это контактный, $c$ помощью термоэлектрических термометров (термопар), и бесконтактный, в котором датчиком выступает полупроводниковый иммерсионный болометр БП1-2, работающий 8 инфракрасной части спектра.

Предложены способы, схемы и приспособления для определения температур рабочих поверхностей скребков смесителей огнеупорной массы и штампов для прессования огнеупоров в производственных условиях. А также поверхностей трения образиов при испытаниях на стандартной установке Х4-Б и на лабораторном стенде, разработанном в ЗНТУ.

Ключевые слова: износ, температура, термометрия, термопара, лабораторные испытания, установка для испытаний, методика испытаний

(C) Андрущенко М.І., к.т.н., Куликовський Р.А., к.т.н., Акритова Т.О., асп., Капустян О.Є., к.т.Н., Бриков М.М., д.т.Н., Осіпов М.Ю., к.т.Н. 
Andrushchenko M., Ph.D., Kulykovskyi R., Ph.D., Akrytova Taisiia

Kapustian O., Ph.D., Brykov M., Ph.D., Osipov M., Ph.D.

Zaporozhye National Technical University

\section{RESEARCH OF METHODS AND THERMOMETRY DEVICES FOR DETERMINING THE TEMPERATURE OF SURFACE FRICTION OF DETAILS IN THE PROCESS OF WEAR}

It is shown that temperature is one of the main parameters, which negatively affects the wear resistance and the ability of self-strengthening of the friction surface of parts in the process of wear. This is especially true of materials with a large amount in the structure of the metastable austenite. Depending on the chemical composition of the metastable austenite, the negative effect of friction surface heating can already affect at temperatures of about $100^{\circ} \mathrm{C}$. Therefore, an informed choice of materials and their structure for manufacturing or restoring parts requires information on the temperature level that occurs on the friction surface during wear. Equally important is the temperature value in the heat-affected zone during welding or welding.

The paper discusses two basic methods of thermometry, which are best suited for determining the temperature of working surfaces of parts. Contact method using thermoelectric thermometers (thermocouples) and non-contact, in which the sensor is a semiconductor immersion bolometer BP1-2, operating in the infrared part of the spectrum.

Methods, schemes and devices for determining the temperatures of the working surfaces of the scrapers of the refractory mass mixers and dies for pressing refractories under production conditions are proposed. As well as friction surfaces of samples when tested on a standard installation X4-B and on a laboratory bench, developed in ZNTU. method

Keywords: wear, temperature, thermometry, thermocouple, laboratory tests, test setup, test

(C) Андрущенко М.І., к.т.н., Куликовський Р.А., к.т.н., Акритова Т.О., асп., Капустян О.Є., к.т.н., Бриков М.М., д.Т.н., Осіпов М.Ю., к.т.н. 